\section{Research Article}

(C) 2020 Noor et.al.. This is an open access article licensed under the Creative Commons Attribution-NonCommercial 4.o International License (https://creativecommons.org/licenses/by-nc/4.o/)

\title{
The Academic Supervision of the School Principal: A Case in Indonesia
}

\author{
Dr. Idris HM Noor \\ Senior Researcher, \\ Office of Educational Research and Development, \\ Ministry of Education and Culture, Indonesia

\section{Dr. Herlinawati} \\ Senior Researcher, \\ Office of Educational Research and Development, \\ Ministry of Education and Culture, Indonesia

\section{Dra. Etty Sofyaningrum} \\ Senior Researcher, \\ Office of Educational Research and Development, \\ Ministry of Education and Culture, Indonesia
}

DOI: https://doi.org/10.36941/jesr-2020-0o67

\begin{abstract}
A principal plays a vital role in managing school and improving teacher's quality teaching instruction in the class. This study explores the academic supervision of the principal in helping teachers improve their teaching profession to enhance students' learning outcomes. Secondary data were collected from the document of basic data of education of the Ministry of Education and Culture. The online survey and FGD as well as interview are used to collect data about the number of principal's monitoring teacher's teaching activities in the class, the implementation of the principals' supervision, and the improvement of teaching activities after supervision. The descriptive technique is used to analyse the data (Strauss dan Corbin, 1990, p. 62). The study reveals that the supervision follows the procedure (planning, implementation, reporting, and follow-up results of the supervision) as a guide of monitoring. However, in the implementation, all processes in the guidelines are not appropriately followed, due to the heavy burden of the principal's school task.
\end{abstract}

Keywords: principal school, academic supervision, teacher, teaching, learning

\section{Introduction}

The quality of education is one of the demands of Indonesia in order to be able to compete with other countries. The quality of education is always associated with the achievement of students both in the form of school examination, national examination, and the surveys conducted by various institutions.

The survey conducted by Programme for International Student Assessment (PISA in 2018 about Science, Reading, and Mathematics shows that Indonesia scored 396 in Science, 371 in Reading, and 
379 in Mathematics. Besides, the Indonesia National Assessment Programme (INAP) survey also reveals that $77.13 \%$ of students find difficult in understanding Mathematics, $46.83 \%$ Reading, and 73.61\% Science (Assessment and Testing Center, 2017). Upon closer observation of these surveys' results, Indonesian students' scores in all three areas have not significantly increased from 2009 to 2015 and with slow growth. The SMERU Research Institute through its program titled "The Research on Improving Systems of Education (RISE) in Indonesia" published a research finding in 2018 that Indonesia's efforts to improve learning as measured by Science, Reading and Mathematics scores are lower than those of other OECD countries (OECD, 2019). A study conducted by INOVASI institution in 2016 concluded that there are five factors in the students' learning quality at school: (i) teaching practice; (ii) teachers; (iii) students; (iv) school's internal or learning environment; and (v) school's external environment. Several other studies also found that the student learning achievement correlates with the quality of teachers, particularly the quality of teaching practice. Therefore, the three basic competencies affect a quality of student learning. An important factor that supports teacher quality is the supervision of the school principal. A research about students' literacy and arithmetic conducted by INOVASI institution (2016) found that the principal's managerial skills and their supervision have the most substantial on student learning outcomes, especially on arithmetic. Other studies (Subandono, 2011; Firmaningsih, 2015) also highlighted the vital role of the school's principal on school development and student learning outcomes.

The successful supervision depends considerably on the supervisors' ability to forge a cohesive working group among his subordinates through the five principles of Human Relations School of thought which are the humility, responsibility, human dignity, condentiality, and changeability assumptions (Adu, Akinloye, Olaoye, 2014).

In 2015, 60\% of all registered principals in all levels took the Principal Competency Test that was conducted by the Ministry of Education and Culture. The results for each province is shown in Figure 1. The results showed that $43 \%$ of all participating school principals scored below the national average (55.8) and that the supervision dimension scored the lowest on average compared to the other two aspects, namely Managerial and Entrepreneurship.

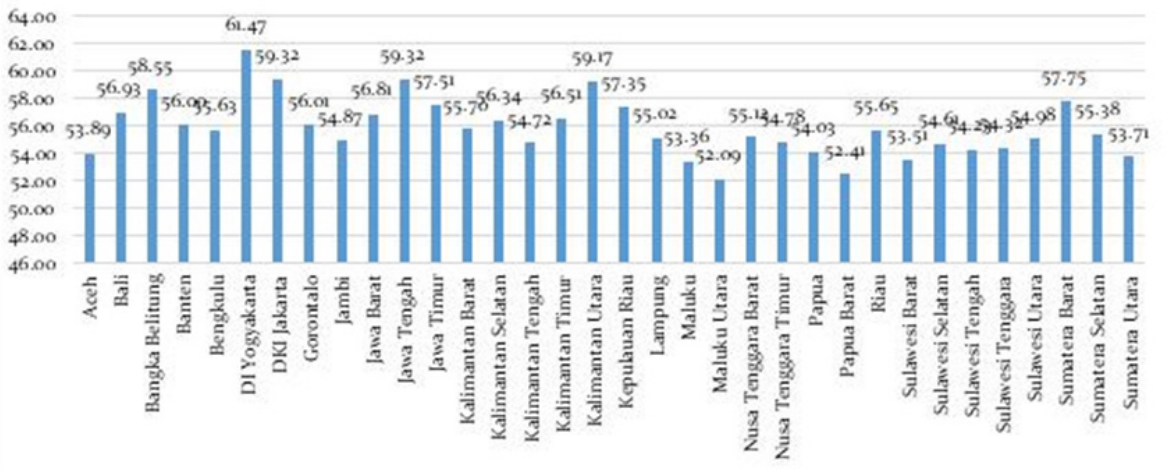

Figure 1. Principal competence Test result year $2015(\mathrm{~N}=166334)$

Source: Directorate of Human Resources Development, Ministry of Education and Culture, 2018

The relationship and communication between principal and teachers consider to be a key reason why the pricipals' supervision towards teachers has not produced a positive impact yet on school quality. Several studies (Subandono, 2011; Maulana, 2012; Firmaningsih, 2015) highlighted that the principal's position as a supervisor might provide ample opportunities for teachers or other education professionals to be involved in the school policy-making processor the learning system reform 
However, the position was instrumental in creating a pleasant working environment. Furthermore, Sulistiono (2017) found that the profession of the principal was less active because of lack of information, readiness, and the required competence for principal removed from that of the teacher. Based on the problems, the study was conducted to answer how principal's academic supervision can improve the school's quality. The study aimed to explore the implementation of the principal's academic supervision toward teacher's teaching practices in the classroom.

\section{Literature Review}

The Law No. 20 Year 2003 on the National Education System stated that education personnel are members of the profession who are appointed to support the implementation of education. The education personnel include the management staff of the education providers among other types of education personnel (Ministry of National Education, 2003). Wiles and Bondi (1986) highlighted that school management and oversight are vital factors to learning and link to school leadership.

\subsection{School Principal}

As an organization, the school consists of physical elements (e.g. buildings, facilities and learning infrastructure) and nonphysical elements (e.g. the development of organizational resources, human resources). To manage these elements, it is essential that the school leaders must have the necessary skills such as leadership, interpersonal, teamwork, personnel administration and evaluation skills (Wiles \& Bondi, 1986). According to Prihatni (2014), education personnel work performance, including that of a principal, a school a supervisor, and a teacher are major contributors (62.73\%) to improve school quality compared to the remaining $37.27 \%$, which comprises of variables such as infrastructure, financing, and parent participation (Prihatni, 2014). The principal expects to have a broad vision and professional insight in education planning, managerial, and supervision. Several studies (Kimbrough \& Burket, 1990; Fattah \& Ali, 2008) stated that the school principal has several leading roles, including internal functions (e.g. relevant to the curriculum, student, personnel, facilities and infrastructure) and external roles (e.g. communication with parents, the surrounding community, business or industries stakeholders). Morris (1985) in Sulthon (2009) identifies several effective leaders' characteristics that are: a clear understanding of what is expected of them, professional, innovative and adaptable.

The leadership style and the academic supervision of the school principal might affect teacher performance (Nurwati, 2015). In addition to supervising the teacher's teaching practice, the principal's needs to encourage teachers to develop their ability through training, study assignments formally, workshops either through independent study or through professional learning communities.

\subsection{Supervision of education}

Supervision is defined as the process to asses the teacher's teaching and learning activities in the class (Manullang, 2005). A supervisor described as a set of processes to offer professional guidance and advice to teachers to improve the quality of instruction and class management. Wiles \& Bondi (1986) in Maulana (2012) stated that education supervision has three dimensions: administration to achieve learning objectives, implementation of curriculum; and instruction according to the plan of learning program and its application.

The supervision function in education is not merely a control to see if all activities been implemented following the plans or programmes made that include determining the conditions or requirements of the personnel and materials necessary to create productive learning environments. In practice, supervision is not only the supervision of teachers and other education professionals to ensure that they have been performing their tasks properly, but also to jointly seek solutions in 
improving learning. Teachers are not considered as only passive implementers, but also are treated as co-workers who have different ideas and experiences needed to be heard and included in the improvement of education efforts. A positive school culture cannot rely solely on administrators, teachers may also make a significant contribution since their attitudes and behaviours directly affect students and have a signicant impact on their classroom, and school climate (Pourdavood \& Yan, 2020) and educational supervision has a positive affect on teachers' professional developmenet (Donkoh \& Dwamena, 2014).

\section{Research Methods}

This study employed a mixed method design (Cresswell, 2010; Arikunto, 200o) using secondary data and comprehensive Focus Group Discussion ( FGD). Data collected were documentation as secondary data, key interviews with resource persons in five selected location: Central Java (Surakarta Municipality), West Sumatera (Tanah Datar District), West Java (Bandung Municipality), West Sulawesi (Mamuju District), and North Kalimantan (Tarakan Municipality). Respondents are experienced principals, teachers, supervisors, and educational experts from iniversities. An online questionnaire is used to collect data about each school's learning environment, in particular regarding academic supervision by the principals. The online survey is used to gather data such as the number of principal's visits within a period and the teacher's evaluation towards the result of the principal's supervision. The processes of data analysis employ examining, categorizing, tabulating frequency of events, recombining evidence, using arrays to display the data, creating displays, ordering the information, using various interpretations, triangulation, and making conclusions.

\section{Research Findings}

\subsection{Academic supervision planning}

Planning is a preliminary part of supervision, which is an integral part of a school's quality improvement. The findings show that most school principals in the five districts planned before monitoring. The steps taken by the principals are in the following table.

Table 1. Operational step of school supervision planning

\begin{tabular}{|l|l|l|l|}
\hline No & Components & Operational step & Results \\
\hline $\mathbf{1}$ & $\begin{array}{l}\text { To develop a supervision program that contains the } \\
\text { objectives, plan of implementation, enforcement, } \\
\text { evaluation, reflection, follow-up plans and appendices. }\end{array}$ & $\begin{array}{l}\text { The principal formed a team of } \\
\text { supervisors. The team, led by the } \\
\text { principal, planned the } \\
\text { supervision program. }\end{array}$ & $\begin{array}{l}\text { Document of } \\
\text { supervision program }\end{array}$ \\
\hline 3 & $\begin{array}{l}\text { Create schedule to supervise all teachers. } \\
\text { identification of subjects, indicators of achievement, } \\
\text { goal formulation, lesson material identification, } \\
\text { learning methods, learning media, learning resources, } \\
\text { learning scenarios, and assessment. }\end{array}$ & $\begin{array}{l}\text { The principal and the team } \\
\text { compiled an analytical } \\
\text { instrument of learning devices. }\end{array}$ & Instruments \\
\hline 4 & $\begin{array}{l}\text { Develop monitoring instruments that contain } \\
\text { monitoring methods: observation, interview/poll, and } \\
\text { Focus Group Discussion (FGD). }\end{array}$ & $\begin{array}{l}\text { The principal and the team } \\
\text { developed monitoring program }\end{array}$ & $\begin{array}{l}\text { Document of } \\
\text { monitoring program }\end{array}$ \\
\hline 5 & $\begin{array}{l}\text { Develop analytical instruments for learning } \\
\text { implementation. }\end{array}$ & $\begin{array}{l}\text { The principal and the team } \\
\text { developed analytical instruments } \\
\text { of learning implementation }\end{array}$ & $\begin{array}{l}\text { Analytical instruments } \\
\text { for learning } \\
\text { implementation }\end{array}$ \\
\hline 6 & $\begin{array}{l}\text { Compiled a supervision record consisting of learning } \\
\text { device plan for reflection and follow-up plan. }\end{array}$ & $\begin{array}{l}\text { The principal and the team } \\
\text { compiled a supervision record. }\end{array}$ & $\begin{array}{l}\text { Supervision note } \\
\text { format }\end{array}$ \\
\hline
\end{tabular}

Source: Work Guide for school Principal, MOEC, 2018 
Although a working guide for principal establishes the planning components that the principal must do before supervision, findings from the field showed that these are not necessarily suitable. Most principals planned guidance at every semester, or twice a year, every semester, monitoring is conducted through various methods because the data required by the principal is also diverse.

At the beginning of the semester, the monitoring is usually done with the curriculum developer team that comprises of teachers that aims to manage time for learning activities within one academic year. The monitoring is also done with a team to plan the needs for teacher capacity development (MOEC, 2017). The establishment of a group of educators has been found in several schools, although the implementation is still limited to the effort to divide and map the existing teachers' duties. Those who do not form a supervision team usually develop supervision instruments independently, although not many of them do so. In general, the principals claimed that they used the previous existing supervision instruments and modified or updated according to the needs of the school principal. Although the work guide published by the Ministry also includes the Teacher Work Assessment (TWA) instrument, as an output for principal's supervision, in its execution, the principals redeveloped the supervision instrument they had used instead.

\subsection{Implementation of supervision}

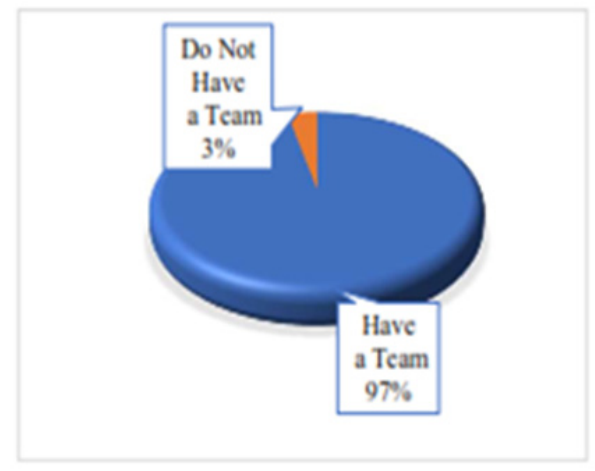

Figure 2: Availability Team $(\mathrm{N}=37)$

Source: Survey of teachers' experience on the supervision of school principals, 2018

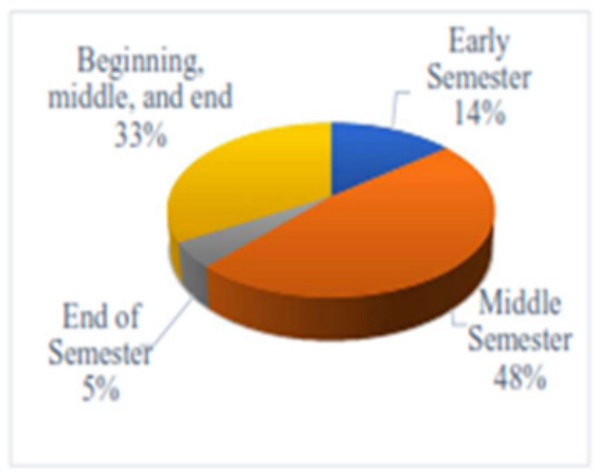

Figure 3: Execution time of supervision $(\mathrm{N}=37)$

Source: Survey of teachers' experience on the supervision of school principals, 2018 
In its implementation, not all teachers had received guidance although the principal has formed a supervision team. Some factors that caused this include time constraints of the supervision team members. Moreover, there is no additional reward or compensation for teachers who have other tasks as a supervision team member.

In carrying out the supervision, normatively a principal can use an individual or group technique (MOEC, 2017). Findings in the five locations show that most principals use individual supervision in the form of class observation and visits. However, there are also some cases where some supervision methods are used together or used interchangeably.

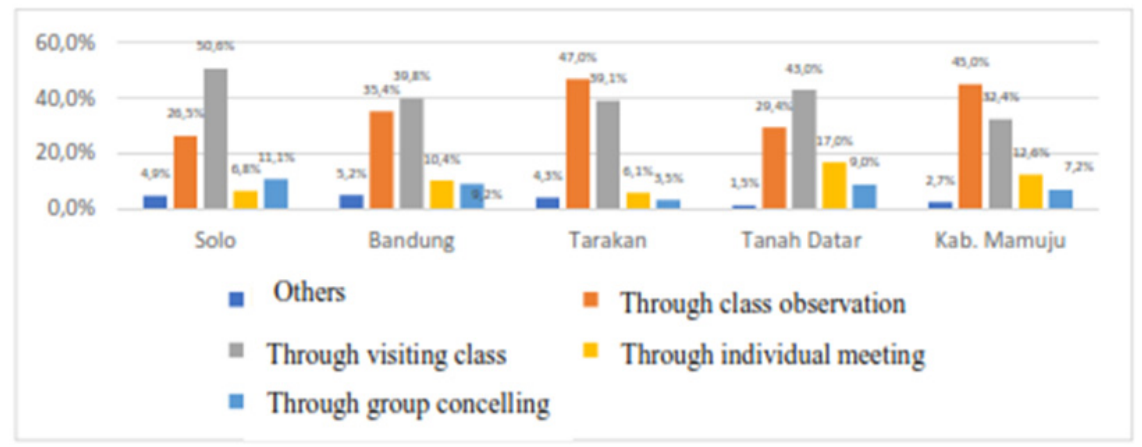

Figure 4: How academic supervisions are carried out in each study location $(\mathrm{N}=\mathbf{2 , 7 6 9 )}$

Source: Survey of teachers ' experience on the supervision of school principals and supervisors, 2018

The findings suggest that supervision method by class visits is the one most frequently employed in some areas such as Surakarta, Bandung, and Tanah Datar. This supervision technique is conducted as an effort to see directly the learning process done by teachers and is one of the techniques of coaching teachers by the principal. Observation techniques are usually chosen by the principal to give a more intact and real picture about the learning process in the classroom. The observation of the class is procedurally passed since the preparation, implementation, closure, observation result assessment is followed up. One of the disadvantages of this supervision technique is the sheer amount of time it takes to observe the classroom. However, class observations were not used as often as class visits. One reason for this is because there are procedures to be taken prior to class observations as well as time constraints. The reason is the procedure before doing the class observation is that the school principal must adequately understand the methods and processes of teaching. The findings also showed that although all principals have educational background or experience as teachers, principal's supervision may not be as effective as it is needed to be in gathering data and information of real classroom activities.

The findings also show that not all principals have the ability to understand techniques, methods and learning although they have a background as a teacher. It is not to guaranted the supervision techniques used by the principal will be effective to gather data and information of real classroom activities.

Inter-class visit is one of the least employed methods in individual supervising. This supervision method is usually used by the principal who has formed a supervision team consisting of several teachers. A supervision team member will have to supervise another member's class and report to the principal. In practice, this method is somewhat difficult to implement because it requires right timing to avoid disturbing the learning in class and it takes time to coordinate in a school with quite some learning groups. Moreover, the findings also showed that teachers were overwhelmed with the workload of teaching and supervising.

In general, the principals involved their supervision teams formed, and only a small percentage 
of principals opted to conduct the supervision by themselves. In some areas, the academic supervision was also done by parents, supervisors, school committees, parents and educational practitioners.

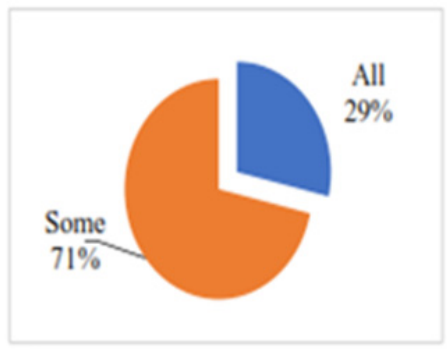

Figure 5: Scope of supervision to master. $(\mathrm{N}=37)$

Source: Questionnaire Principal, 2018

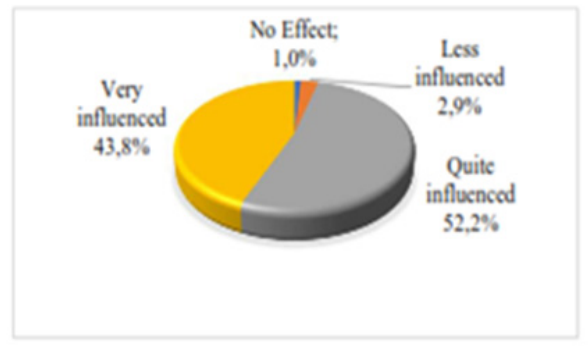

Figure 6: Influence of the principal's supervision on capacity building and teacher performance. $(\mathrm{N}=2,769)$

Source: Survey of teachers ' experience on the supervision of school principals and supervisors, 2018

The study also found a few interesting cases in several areas, including supervision conducted by external parties. This happend at public school with special needs students but was not originally an inclusive school. The number of special needs students kept increasing, and the school found a challenge in providing regular education that was given in other schools. In this environment, the principal established a program to hire a special teacher companion who will assist teachers from students' parents/caregivers, higher university students majoring in Special Needs Education and graduates of Psychology. Besides assisting teachers in the classroom, these teacher companions also assist the principal preparing a written report each week that describes classroom learning environment.

Another notable practise was reducing shifting the classroom visit to face-to-face personal consultation between the principal and teachers. This was done due to teacher's reluctance of having an observer in the classroom and in order not to disrupt the psychological setting in the classroom.

Other findings in some areas are best practices of the supervision methods performed by the principal involving teams/other parties outside the school. This supervision is performed on schools with specific student input. The result of a public elementary school that was originally a pilot, which has a number of students from Children with Special Needs (CSN) when the school is not an inclusive school. The number of CSN students in the school, the longer the number increases and gives the school a challenge to continue providing education services such as other public schools. In conducting supervision, the principal enforces a special companion teacher Program and volunteers 
in order to help the parents face the students, by holding a "helper" in the class. Providing learning services to students who are generally CSN, give their own challenges, so it takes certain practices so that the learning given is still appealing to the CSN, as well as other non- CSN students. In addition to assisting teachers in the learning process, the "helpers" also assist the principal in conducting academic supervision in the classroom. "Helper" makes written reports submitted to the principal periodically on a weekly basis about the conditions of learning in the classroom, and completes the report the teacher provided the class tobecome the input and consideration material principal's policy for internal schooling.

Other findings showed that not all regions stipulated a regulation on the reporting of school supervision conducted by the principal and school supervisor, which is reported periodically to the local Education Office. Only Bandung's Municipal Education Office, for example, has stipulated that all principals and school supervisors write their supervision report once a month and provide an online report through the Electronic Remuneration Work (e-RW) application every day at 4 p.m. The report will then determine the amount of their monthly regional allowance. Other regions have no similar policies, although the Employee Performance Objectives (EPO) system for principal and supervisor has implemented. Moreover, there is a lack of report filling system and archiving mechanism in most regions which contribute to a lack of follow-up by the Provincial Education Office.

However, most principals claimed to follow up teacher's supervision results periodically, and only a small percentage claimed to do so occasionally. The findings showed that the usual follow-up employed by the school principal is inviting teachers to discuss the results of previous supervision in a meeting or other forum attended by several teachers. The school principal will re-evaluate by conducting follow-up supervision and give recommendations on professional capacity development that will support teachers' teaching practices.

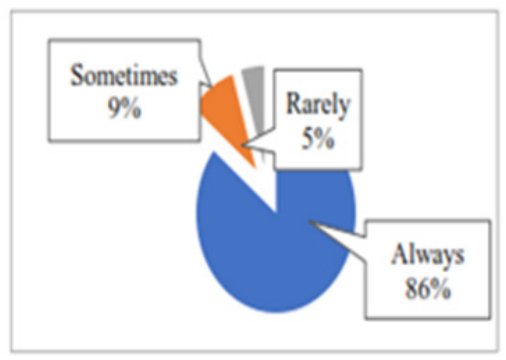

Figure 7: Intensity in providing feedback result of supervision. $(\mathrm{N}=37)$

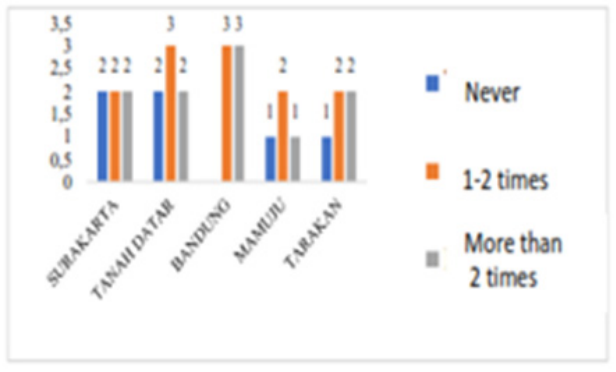

Figure 8: Intensity of training received by the principal $(\mathrm{N}=37)$

The FGD results revealed that there were several obstacles in implementing supervision, as follow: 
1. Although the principal does not have a task to teach anymore, they are still responsible for fulfilling the criteria for the eight national standards of education.

2. Several principals also have a limited understanding of the National Standards of Education, therefore limiting their capacity and in some cases, relying on the school supervisors to monitor school quality.

3. Principal recruitment is still influenced by the local political interests although there have been some improvements. As a result, selected principals may not come from the pool of accomplished teachers or education personnel and may not have the required skills to become a principal.

4. Lack of monitoring system and follow-up from the supervision. Monitoring is not often done to evaluate if the teacher has improved after the principal's supervision.

5. In several schools, the school's supervision teams had never met to discuss the goals, targets, steps, and follow-up plan after control.

6. There are cases where school supervisors regard themselves higher than the principals and do not position themselves as the principals' partners in improving school quality.

7. Principals and school supervisors rarely evaluate themselves, although there are selfinstruments available.

8. Provincial and District Educationa Office often invite principal for a meeting that make pricipal is rarely at school

In terms of governance, the FGD results showed that:

1. The training or capacity development of principals are not yet distributed well as there are several principals who continuously received training or capacity developments in contrast the rest of them have not received any at all.

2. Not all Provincial Education Offices have the initiative to build a principal' competency through various capacity development programs.

3. Most Provincial Education Offices focus solely on strengthening the principal's managerial competence and on how they conduct school-based management.

\subsection{Equality}

Not all regions have active principal organisations. Although there have been several professional organisations for principals, principals claimed that they had not seen the benefits of having these organisations in supporting their work. Figure 9 shows the school monitoring of teacher changes and improvements after supervision. Findings in the five regions showed that most teachers admitted that the schools have been monitoring changes and development of their teachers after control.

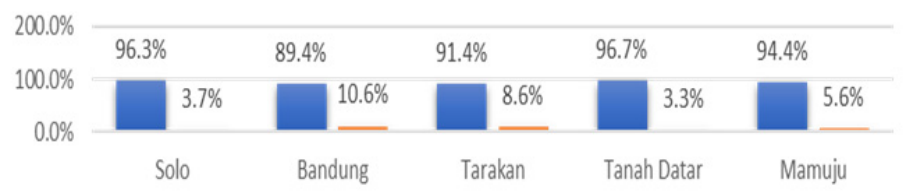

aYes $\mathbf{m}$ No

Figure 9: School monitoring on teacher changes and improvement after supervision $(\mathrm{N}=\mathbf{2 , 7 6 9 )}$

\subsection{A Strategy of strengthening school principal}

From the findings both from the secondary data and the result of the school visit and FGD, there are at least four main problems in the supervision of the principal as it is seen in the following table 2 . 
Table 2: Principal mapping matrix

\begin{tabular}{|c|l|l|}
\hline No. & Problems & School principal \\
\hline 1 & $\begin{array}{l}\text { Human } \\
\text { resources } \\
\text { capacity }\end{array}$ & $\begin{array}{l}\text { 1. Political situation still influences recruitment } \\
\text { 2. Lack of initiative by the school management } \\
\text { 3. Limited opportunities to train school principals }\end{array}$ \\
\hline 2 & Workload & School principles have too many tasks \\
\hline 3 & $\begin{array}{l}\text { Supervision } \\
\text { method }\end{array}$ & $\begin{array}{l}\text { 1. Lack of involvement by the supervision team in planning supervision program } \\
\text { 2. The weak monitoring system in following up the results of supervision } \\
\text { 3. Underdeveloped supervision instrument }\end{array}$ \\
\hline 4 & $\begin{array}{l}\text { Communication } \\
\text { patterns }\end{array}$ & $\begin{array}{l}\text { 1. Principal supervisor relation in which the supervisors think they are superior } \\
\text { 2. The role of the school principal within the school is a manager } \\
\text { 3. The principal puts the supervision as a high-stake assessment which } \\
\text { determines the quality of a school and therefore tries to condition the school, } \\
\text { not providing a real picture }\end{array}$ \\
\hline
\end{tabular}

Source: Result of data analysis, 2018

\section{Discussion}

This study is to explore the academic supervision of the principal in helping teachers improve their teaching profession in enhancing students learning outcome. The findings of the study show that most principals in five districts make a plan before conducting supervision in the class. This is important due to the preliminary part of monitoring is an integral part of a school's quality improvement (Lunenburg, 2010). The study also found out that in its implementation, not all teachers were monitored although the rincipal has formed a supervision team. This is caused by the time constraints of the supervision team members and no additional reward or compensation for the team. Besides, most teachers know that they are not strictly supervised (Donkoh and Dwamena:2014), but supervision was more effective (Iroegbu \& Eyo, 2016). The principal should also provide conducive climate, applies reward and punishment policy, and optimizes managerial functions especially in monitoring (Marzuki \& Lampuasa, 2019).

In doing supervision, most principals in five sample research location use visit class to observe the teacher's teaching activities. The principal becomes a leader in serving teachers and students (Makarim, 2019) and work collaboratively as well as perform excellent communication affect satisfied learning for students (Firmaningsih, 2015). However, research reveals that although all school principals have educational background or experience as teachers, principal's supervision may not be as effective as it was hoped to be in gathering data and information of real classroom activities. Therefore, the monitoring should be done regularly and systematically (Weerakoon, 2017), and teachers must feel that the supervisor is there to serve them and to help them become more effective teachers (Panigrahi, 2012).

Only a small percentage of principals opted to conduct the supervision by themselves, and there is a positive weak significant relationship between supervision roles of heads and academic performance of students (Sey \& Maina, 2016). Not all regions stipulated a regulation on the reporting of school supervision conducted by the school principal and school supervisor, which must be reported periodically to the local Education Office. The constrains in implementing monitoring are also influenced by the heavy burden of a principal in fulfilling the criteria for the eight national standards of education, lack of follow up of the result of the supervision, principals and school supervisors rarely evaluate themselves, and not all regions have active principal organisations. 


\section{Conclusion}

Based on the discussion, it can be conluded that the most principals in the five districts did planning before supervision. However, there are still many constraints in implementing the supervision in the class. One of them is the workload of the principal such as to carry out managerial tasks and entrepreneurship development. In addition, there is a heavy burden of a principal in fulfilling the criteria for the eight national standards of education. The principal should fulfill the eight standard of education such the standard of school quality improvement. Others, principal are rarely at school because they are busy attending meeting and activities at the provincial and district education office or other units outside school.

To overcome the limitations of the principal in doing monitoring, most principals form a team of monitoring consisting of senior teachers who experienced in learning and teaching. The task of this supervision team is to help principals monitor the teachers' teaching activities and perform supervision phases since the planning, implementation, evaluation, reporting and supervision followup. The supervision team is also responsible for the development of supervision instruments used.

However, the supervision team is less maximized doing supervision tasks because of the lack of monitoring techniques of the team and no compensation or reward from the principal both material and non-material.

\section{Recommendation}

Based on the finding of this study, the researchers would like to suggest several factors to be considered in improving the work of principal: Firstly, the principal should reduce their workload other than the main task they keep as a principal. Other additional work such as attending meeting outside school which is not closely related to the work of principal must not be done. By reducing the workload of the principal, the main task of the principal will be handled well. Therefore, it is recommended that the district and provincial educational office should not involve the principal to attend the meeting which is not related to the main work of the principal. Besides, it needs a close cooperation and collaborative activities between principals, school supervisors, and Education Office because the academic supervision is also a task of supervisors. They can share their experience and data of the result of academic control they have.

Secondly, the team of monitoring which is formed by principal should be given a reward both incentives (an additional income both material and non-material) and carrier improvement. By giving an incentives, it is hoped that the team will work hard to improve their teaching activities, then later the students' outcome will increase significantly.

Finally, for the District Educational Officer, it is suggested to keep a close relation to both supervisors and principals in order they can do their task well. It needs due the work of supervision cannot be separated from the work of the principals, school supervisors, and District Education Office.

\section{Acknowledgement}

The author is grateful to Office of Educational Research and Development for funding the study, the District Educational Office of Surakarta Municipality (Central Java), District Educational Office of Bandung (West Java), District Educational Office of Tanah Datar (West Sumatera), the District Educational Office Mamuju (West Sulawesi), and the District Educational Office Tarakan (North Kalimantan) for the recommendation to allow their schools to participate in this study. The deeply thankful is also address to principal of Senior Secondary School who have participated in this study. 


\section{References}

Adu, E.O; Akinloye, G.M; \& Olaoye, O.F (2014). Internal and external school supervision: Issues, Challenges and wayforward. International Journal of Educational Sciences. 7(2)2. Retreaved from https/www. tandforline. com/doi/abs/10.1080: /o9751122.2014.11890189.

Arikunto, S. (200o). Research Procedure of an Approach to Practice. Jakarta: Rineka Cipta

Indonesian National Assesment Programme (INAP) (2020). Assessment and Testing Center, Office of Educational and Cultural Research, Ministry of Education and Culture. Retreaved from https://puspendik.kemdikbud. go.id/inap-sd/kategori.

Cresswell, J. W. (2010). Research Design. Translated by Fawaid, Achmad. An Approach to Qualitative, Quantitative, and Mixed Methods. Pustaka Pelajar Yogyakarta.

Donkoh, K. E; \& Dwamena, E.O. (2014). Effects of educational supervision on professional development: Perception of Public basic school teachers at Winneba, Ghana British Journal of Education 2(6), 63-82, Published by European Centre for Research Training and Development UK (www.eajournals.org).

Fattah, N; \& Ali, M. (2008). School-based Management. Jakarta: Open University.

Firmaningsih, Y. (2015). The Role of the principal's instructional leadership at schools in Indonesia [Unpublished thesis]. Department of Education Institute of Educational Leadership University of Yogyakarta

INOVASI Institution (2016). A Systematic Review: Interventions, Practices, and Contextual Factors Related to Indonesian Students Literacy and Numeracy: [Unpublished] Innovation for Shool Children.

Iroegbu, E.E; \& Eyo, E. E. (2016). Principals' instructional supervision and teachers' effectiveness. British Journal of Education, 4(7), 99-109, European Centre for Research Training and Development UK (www.eajournals.org).

Kimbrough, R.B; \& Burkett, C.W. (1990). The Principalship: Concepts and Practices. Englewood Cliffs: Prentice Hall, Inc.

Lunenburg, F.C. (2010). The Principal and the school: What Do Principals Do?. National Forum of Educational Administration and Supervision Journal 27(4).

Manullang (2005). Management Basics. Yogyakarta: UGM University Press.

Marzuki, A.G., \& Lampuasa, S. (2019). The Roles of school principal leadership in developing English teachers' creativities in Palu. Al Taklim Journal 26 (3), 267-279. Retreaved from http://dx.doi.org/10.15548/jt.v26i3.517.

Maulana, A. A. (2012). Perception of school supervisor and teacher towards school supervisor role in improving HIGH school education quality in Cirebon City [Unpublished thesis]. Faculty of Social and Political Sciences, Administrative Science Program, University of Indonesia.

Makarim, N.A. (2019). Exposure to Scientific Oration. Ministry of Education and Culture of school leadership at the school and supervisor of principal coordination meeting in Jakarta. MOEC.

Ministry of Education and Culture. Directorate of Educational Resources, Directorate General of Teachers and Education, MOEC (2017). A Principal Work Guide.

Ministry of National Education (MOEC). The Law No. 20 Year 2003 on the National Education System

Nurwati, T. (2015). Strengthening the leadership of the school principal in the scope of intra and extra school. Cendikia Journal, Center for Language and Culture Studies, Surakarta, Indonesia, 9(1).

OECD (2019). Programme for International Student Assessment (PISA) (2018) Results (Volume I): What 15-yearold students in Indonesia know and can do, PISA, Indonesia - Country Note - PISA 2018 Results, OECD Publishing, Paris, Retreaved from https://www.oecd.org/pisa/

Prihatni, D. (2014). The influence of school leadership behaviour and teachers ' work satisfaction of school quality (a descriptive analysis study of Senior Secondary School in Sumedang district). Journal of Education and Learning, State University of Malang, 3(3).

Pourdavood, R.G; \& Yan, M. (2020). Becoming Critical: In-service Teachers' Perspectives on Multicultural Education. International Journal of Learning, Teaching and Educational Research 19(2). 112-135, Retreaved from https: /doi.org/10.26803/ijlter.

Sulistiono, A.A. (2017). A Study of the Manpower Management: Profession of school principals and supervisors. Policy Research Center, Office of Educational Research and Development, Ministry of Education and Culture.

Sulthon, M. (2009). Building Teacher's Spirit work. Yogyakarta: Laksbang PRESSindo

Sey, V.R.A; \& Maina, B. (2016). The role of effective supervision on academic performance of senior high schools in Ghana. Journal of Arts \& Humanities, 5(4), 73-83. Retreaved from https:/www.theartsjournal.org/ index.php/site/article/view/ 932/4.

Strauss, A; \& Corbin, J. (1990). Basic Qualitative Research. Grounded Theory, Procedures and Techniques, London: Sage Publications, Inc. 
Subandono, H. (2011). Perception of a school supervisor and teacher towards school supervisor role in improving HIGH school education quality in Cirebon City [Unpublished thesis]. Faculty of Social and Political Sciences, Program of Administrative Sciences, specificity of administration and education policy. University of Indonesia.

Weerakoon, W.M.S. (2017). School-based instructional supervision process: issues encountered By Supervisors and Teachers. Department of Secondary\&Tertiary Education. Faculty of Education, Open University of Sri Langka, Nawala, Nugegoda. Retreaved from https:/www.researchgate.net /publication/320558114

Wiles, J., \& Bondi, J. (1986). Supervision A Guide to Practice. Ohio: Charles E. Merrill Publishing Company. 